\title{
The influence of operating conditions of the marine gas turbine engine on the level of emission of pollutants contained in the exhaust
}

Pollution emission tests from turbine engines used for the main propulsion of vessels require measurement of the concentration of harmful compounds in the exhaust and assessment of the exhaust gases mass generated by the engine. The concentration of harmful compounds can be determined in a direct way by measuring it in the stream of exhaust gases. However, due to the large output of exhaust gases, the mass of exhaust gases must be determined indirectly. To do this it is necessary to carry out a series of tests and analyzes that will enable parameterization of operating conditions. The obtained parameters and functional relations between them can be used to assess the mass of generated exhaust gases. The article presents analyzes related to the methodology for assessing the mass of exhaust gases generated by the main propulsion turbine engine of the vessel, and the manner of their use in the assessment of emission of harmful exhaust gases.

Key words: gasturbine, ship, emission, pollution

\section{Introduction}

The assessment of emissions of harmful compounds in the exhaust of turbine engines propulsion systems of vessels is associated with the activity in the field of determining the impact of various types of technical facilities on the human environment. Particular attention is paid to the conditions of exploitation of the objects and the resulting consequences. In the field of means of transport exploitation, power generation of the drive is of great importance in the aspect of the impact on the environment. The combustion engine is responsible for generating energy for the purpose of carrying out the function of destination of the majority of means of transport. It converts chemical energy contained in fuel into mechanical energy using the combustion process to generate heat required for the energy conversion process. The consequence of this is the formation of exhausts containing harmful compounds in their composition $[5,6,9,10,12]$.

Turbine marine combustion engines, due to their properties, constitute only a few percent share in the entire population of marine combustion engines. Due to economic reasons (relatively high efficiency, low-quality fuel consumption), propulsive compression-ignition internal combustion engines are used in the majority of propulsion and marine power plants of vessels. For the most part, works related to environmental impact analysis of vessels, as well as development works carried out under various projects refer mainly to civil communication vessels, transport vessels and compression-ignition engines, which are used to drive them $[2-4,7,8,11]$. However, so far only a few research have been taken to assess the emission of pollutants emitted in the exhaust of marine turbine engines with military application, regarding their specific operating conditions $[1,13,14]$.

In connection with the above, tests were carried out related to the measurement of carbon dioxide, carbon monoxide, hydrocarbons and nitrogen oxides in the exhaust gas of turbine engines during the cruise of the FFG-7 ship. During the tests, the results of measurements of the concentration of harmful exhaust compounds were recorded while simultaneously recording the values of the operational parameters of the engines and the entire drive system. A comparative analysis of the recorded data was made, which made it possible to assign particular engine performance, propulsion system and ship a proper value of the concentration of harmful exhaust gas compounds. Knowing the concentration values of harmful compounds in relation to particular operational parameters of the objects, an analysis was carried out, from which functional dependences of ecological parameters were obtained in relation to the engine's operational parameters.

\section{Research object}

The research was carried out with the use of two LM 2500 marine turbine engines from FFG-7 frigate propulsion system (Fig. 1). LM 2500 engines are "milled" turbine combustion engines that are widely used on modern warships and civilian vessels (Fig. 2).

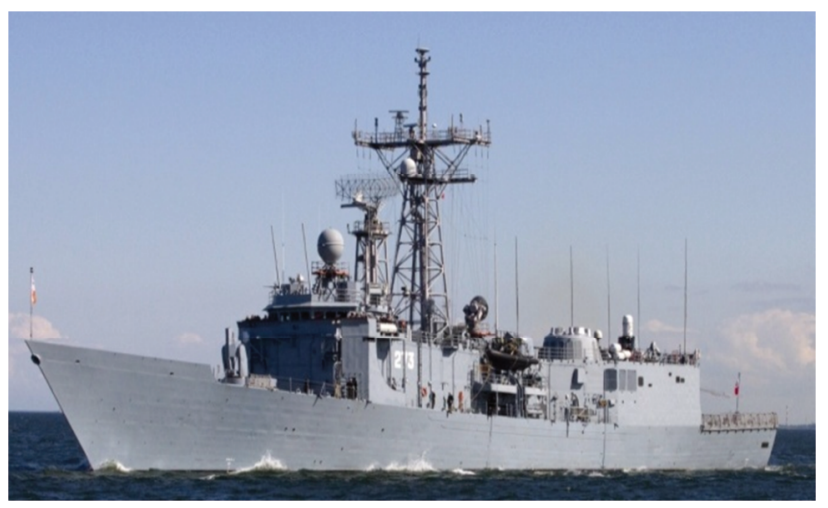

Fig. 1. FFG-7 class ship [16]

The basic structural elements of the engine are:

- 16-stage axial compressor with maximum pressure ratio of 18 ,

- an annular combustion chamber equipped with 32 injectors,

- 2-stage gas generator turbine with cooled blades,

- 6-stage power turbine. 
An integral part in ship constructions is the intermediate shaft transmitting the torque of the drive turbine to the reduction gear.

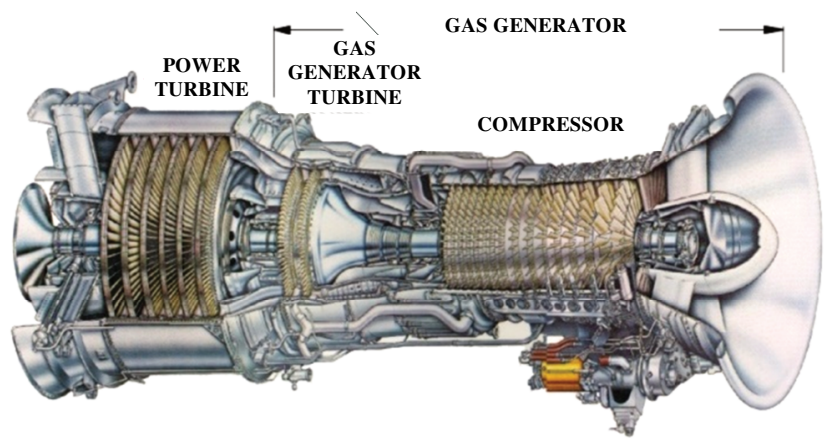

Fig. 2. LM 2500 gas turbine engine [17]

Measurements of the energy parameters of the medium, made in the characteristic control sections of the engine, are an important source of diagnostic information on the state of the constructional structure of its flow part. The presented schematic diagram of the LM 2500 engine (Fig. 3), with the control sections of the flow part marked, makes it possible to display the distribution of measuring points. Measured and determined engine operation parameters with their measuring range, expressed in units valid in the ship's engine room, are shown in Table 1.

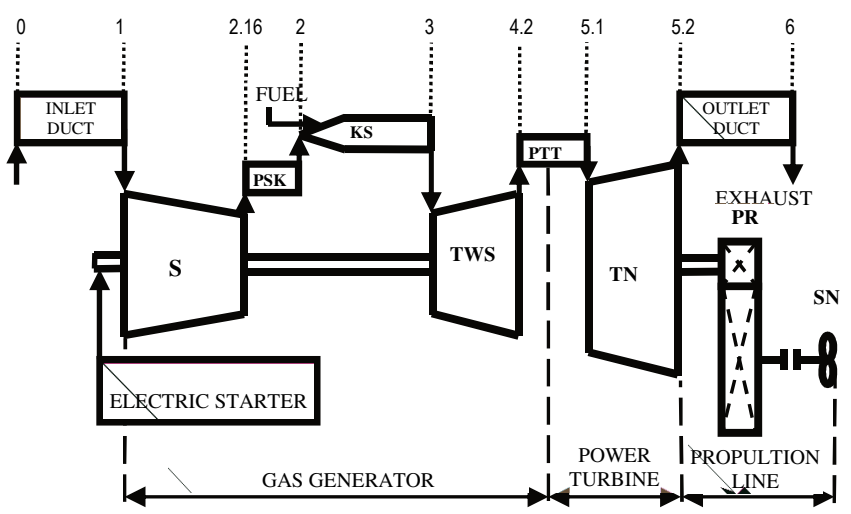

Fig. 3. Schematic diagram of LM 2500 gas turbine engine

The location of the turbine engine in the ship's engine room requires ensuring that its inlet is supplied with a proper stream of air mass and the outlet of gas generated from the exhaust system. For the Oliver Hazard Perry type frigate, equipped with two LM 2500 turbine engines, vertical air intake ducts and vertical exhaust gas channels (Fig. 4) with a length of about $15 \mathrm{~m}$ were designed. The air from the inlet channel is mainly directed to the engine inlet. A small part of the air from the intake duct, taken through the side duct, is led into the interior of the container engine body in order to ensure air exchange and proper temperature around the running engine. The air flowing around the external elements of the engine, located in the container housing, ultimately is directed to the outlet channel, where it mixes with the exhaust gases generated by the engine. Depending on the need to ensure proper parameters, the air flowing from outside the engine is properly prepared in terms of obtaining the required temperature using the cool- ing system and heaters, as well as the required flow speed inside the container housing, controlled with the use of fans. The Semtech-DS exhaust gas analyzer was used for measurements of exhaust components concentration in the exhaust gases, the characteristics of which are presented in Table 2.

Table. 1. Operating parameters LM 2500 engine

\begin{tabular}{|c|c|}
\hline Name parameter, designation, unit & $\begin{array}{l}\text { Measurment } \\
\text { range }\end{array}$ \\
\hline Barometric pressure $\mathrm{p}_{\mathrm{o}}[\mathrm{hPa}]$ & $800-1040$ \\
\hline Ambient temperature $\mathrm{t}_{\mathrm{o}}\left[{ }^{\circ} \mathrm{C}\right]$ & $-40-+40$ \\
\hline The rotational speed of the gas generator shaft $\mathrm{n}_{\mathrm{GG}}[\mathrm{rpm}]$ & $0-12000$ \\
\hline The rotational speed of the power turbine shaft $\mathrm{n}_{\mathrm{PT}}[\mathrm{rpm}]$ & $0-5000$ \\
\hline The inlet air temperature to the engine $t_{1}\left[{ }^{\circ} \mathrm{F}\right]$ & $-40-+150$ \\
\hline The inlet air total pressure to the engine $\mathrm{p}^{*}{ }_{1}[\mathrm{psig}]$ & $0-16$ \\
\hline Air pressure on the outlet compressor $\mathrm{p}_{2}$ [psig] & $0-300$ \\
\hline $\begin{array}{l}\text { The temperature of the exhaust stream before the power } \\
\text { turbine } t_{4.2}\left[{ }^{\circ} \mathrm{F}\right]\end{array}$ & $0-2000$ \\
\hline $\begin{array}{l}\text { Total pressure of the exhaust stream before the power } \\
\text { turbine }{ }^{*}{ }_{4.2}[\mathrm{psig}]\end{array}$ & $0-75$ \\
\hline Temperature exhaust gas $\mathrm{T}_{6}\left[{ }^{\circ} \mathrm{F}\right]$ & $0-1000$ \\
\hline The fuel temperature before engine $\mathrm{T}_{\mathrm{f}}\left[{ }^{\circ} \mathrm{F}\right]$ & $0-100$ \\
\hline Pressure fuel injectors before $\mathrm{p}_{\mathrm{f}}[\mathrm{psig}]$ & $0-1500$ \\
\hline $\begin{array}{l}\text { Torque (calculated) on the power turbine shaft } \mathrm{M}_{\mathrm{PT}} \\
\text { [LB FT] }\end{array}$ & $0-50000$ \\
\hline Power on the power turbine shaft $\mathrm{P}_{\mathrm{TN}}[\mathrm{KM}]$ & $0-25000$ \\
\hline
\end{tabular}

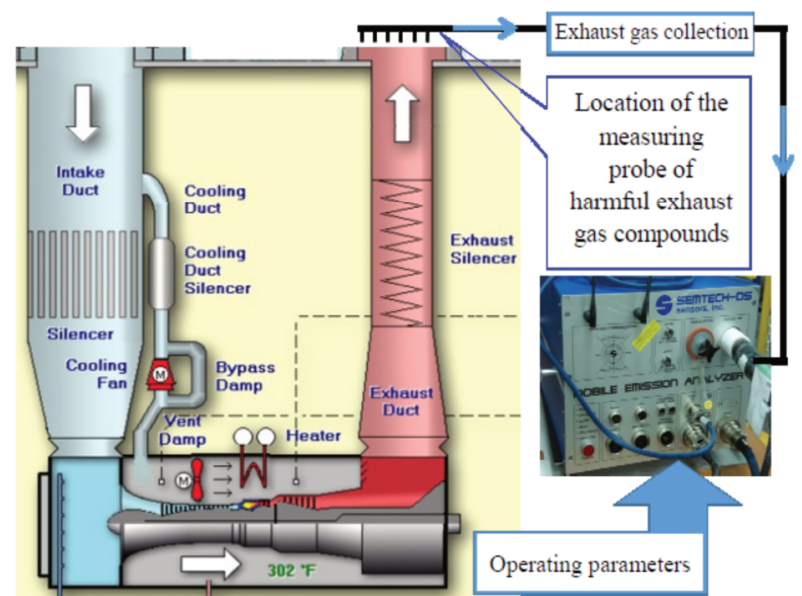

Fig. 4. The air intake system and the exhaust system of the LM 2500 engine installed on the missile frigate with marked sampling point and the Semtech-DS exhaust analyzer view

Table. 2. Characteristics of the Semtech-DS analyzer

\begin{tabular}{|l|c|}
\hline \multicolumn{1}{|c|}{ Name parameter, designation, unit } & $\begin{array}{c}\text { Measurment } \\
\text { range }\end{array}$ \\
\hline The concentration of oxygen $\mathrm{c}_{\mathrm{O} 2}[\%]$ & $0-20$ \\
\hline The concentration of carbon monoxide $\mathrm{c}_{\mathrm{CO}}[\%]$ & $0-10$ \\
\hline The concentration of hydrocarbons $\mathrm{c}_{\mathrm{HC}}[\mathrm{ppm}]$ & $0-10000$ \\
\hline The concentration of nitrogen oxides $\mathrm{c}_{\mathrm{NOx}}[\mathrm{ppm}]$ & $0-3000$ \\
\hline The concentration of carbon dioxide $\mathrm{c}_{\mathrm{CO} 2}[\%]$ & $0-20$ \\
\hline
\end{tabular}

\section{Emission of harmful compounds from LM 2500} engines in operating conditions during the cruise

Measurements of concentrations of harmful compounds contained in the exhaust gas of the LM 2500 engine were carried out during the ship's departure to the sea. Two engines in the propulsion system of the unit were tested - 
each engine was tested separately when only one engine in the drive system was running. The measurements were carried out for the range of engine load from idling to load that could be maximally achieved during tests, with the rotor speed of the flue gas generator $\left(\mathrm{n}_{\mathrm{GG}}\right)$ assumed as the parameter setting the measurement points. This parameter was obtained by appropriate changes of the engine fuel supply stream $\left(\mathrm{m}_{\mathrm{pal}}\right)$. The tests were carried out in such a way that in the first step the defined value of the rotational speed $\mathrm{n}_{\mathrm{GG}}$ was set. After stabilization of the engine operation parameters, the selected drive system operating parameters (including the engine) were recorded and the parameters of the exhaust gases flowing out of the engine were recorded too. The working time with a predefined fixed engine load was 300 seconds. The measurement time of both the operating parameters of the drive system and exhaust parameters was 20 seconds with a recording frequency of $1 \mathrm{~Hz}$.

Figures 5-8 presents the changes in the parameters of the exhaust gases of the tested LM $25001 \mathrm{~A}$ and $1 \mathrm{~B}$ engines as a function of the engine load factor expressed by the engine power ratio obtained at the test points to the maximum engine power:

$$
\mathrm{W}_{\mathrm{o}}=\frac{\mathrm{P}}{\mathrm{P}_{\max }}[-]
$$

where: $P_{\max }-$ LM 2500 engine maximum power.

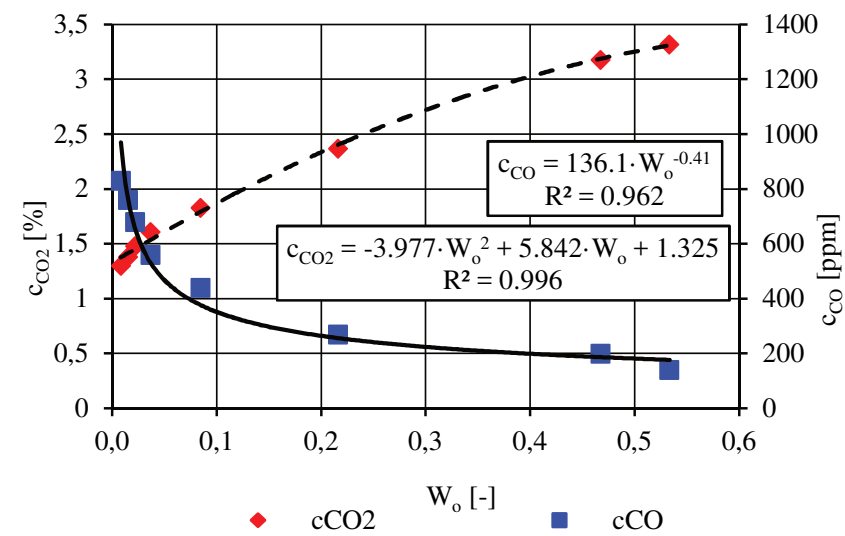

Fig. 5. The concentration of carbon monoxide $\left(\mathrm{c}_{\mathrm{CO}}\right)$ and the concentration of carbon dioxide $\left(\mathrm{c}_{\mathrm{CO} 2}\right)$ in the LM $25001 \mathrm{~A}$ engine exhaust as a function of the engine load factor $\left(\mathrm{W}_{\mathrm{o}}\right)$

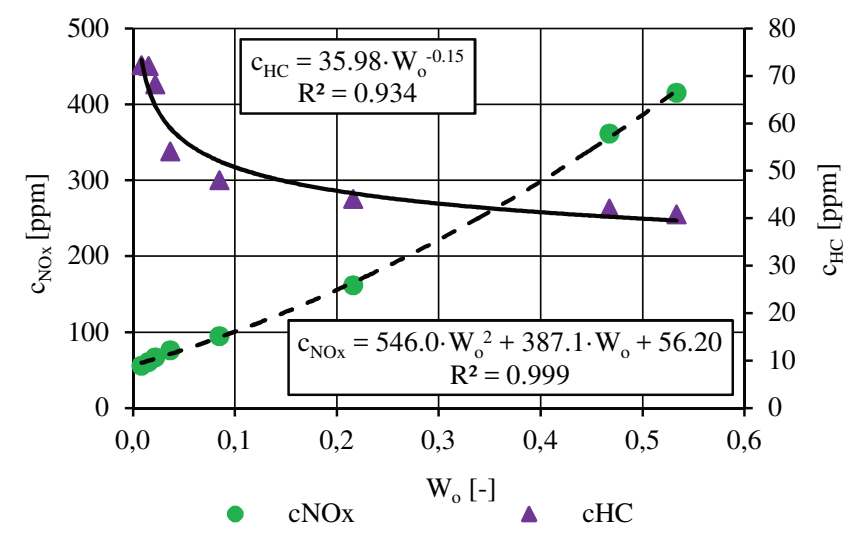

Fig. 6. Concentration of nitrogen oxides $\left(\mathrm{c}_{\mathrm{NOx}}\right)$ and hydrocarbons concentration $\left(\mathrm{c}_{\mathrm{HC}}\right)$ in the LM $25001 \mathrm{~A}$ engine exhaust as a function of the engine load factor $\left(\mathrm{W}_{\mathrm{o}}\right)$

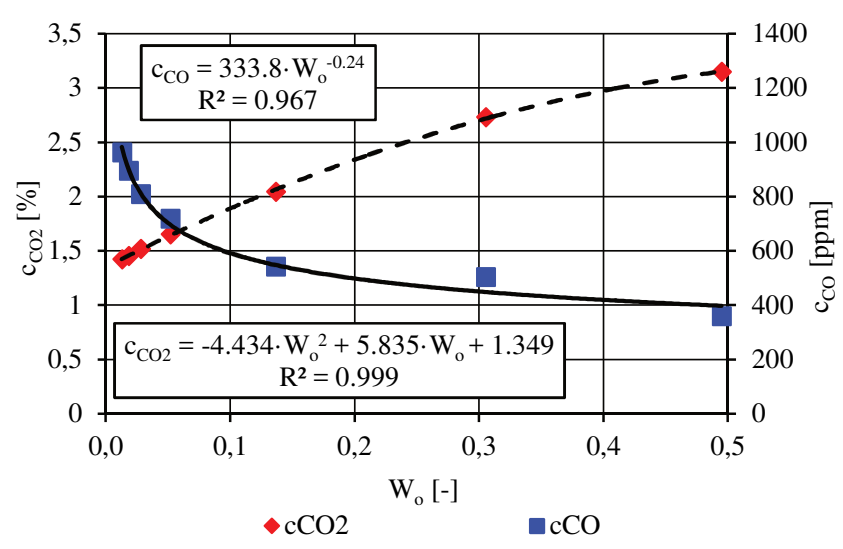

Fig. 7. The concentration of carbon monoxide $\left(\mathrm{c}_{\mathrm{CO}}\right)$ and the concentration of carbon dioxide $\left(\mathrm{c}_{\mathrm{CO} 2}\right)$ in the LM $25001 \mathrm{~B}$ engine exhaust as a function of the engine load factor $\left(\mathrm{W}_{\mathrm{o}}\right)$

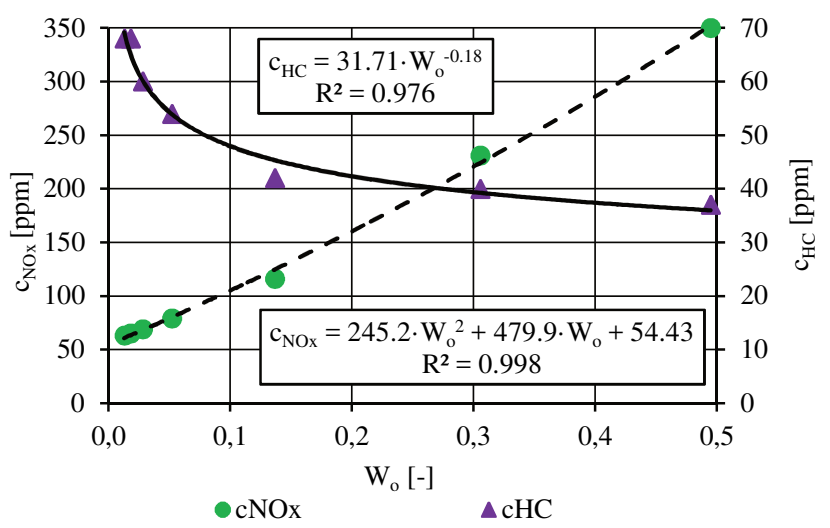

Fig. 8. Concentration of nitrogen oxides $\left(\mathrm{c}_{\mathrm{NOx}}\right)$ and hydrocarbons concentration $\left(\mathrm{c}_{\mathrm{HC}}\right)$ in the LM $25001 \mathrm{~B}$ engine exhaust as a function of the engine load factor $\left(\mathrm{W}_{\mathrm{o}}\right)$

With the increase of the load factor of the LM $25001 \mathrm{~A}$ engine from about 0.01 (engine idle load) to the value achieved during tests of about 0.53 (53\% of the maximum engine power), the oxygen concentration in the exhaust gas decreases from about $18.3 \%$ to about $15.3 \%$. The excess air coefficient, which, as a rule, the turbine engine operation is characterized by significant values in comparison to other internal combustion engines, with the increase of the engine load factor in the above range decreases from about 10.5 to about 4.4. As the engine load increases, the concentration of carbon monoxide decreases from about $830 \mathrm{ppm}$ to $140 \mathrm{ppm}$, while the concentration of carbon dioxide increases from about $1.3 \%$ to about $3.3 \%$. The concentration of nitrogen oxides during this time increases from about $56 \mathrm{ppm}$ to about $415 \mathrm{ppm}$, and the concentration of hydrocarbons decreases from about $72 \mathrm{ppm}$ to about $40 \mathrm{ppm}$.

A similar character of changes in concentrations of registered exhaust components is found in the exhaust gas of the LM $25001 \mathrm{~B}$ engine. With the increase of the engine load factor $1 \mathrm{~B}$ from about 0.01 to the value achieved during tests of around 0.5 (50\% of the maximum engine power), the oxygen concentration in the exhaust gas decreases from about $17.9 \%$ to about $15.6 \%$. The excess air coefficient decreases from about 9.6 to about 4.6. As the engine load increases, the concentration of carbon monoxide decreases from about $960 \mathrm{ppm}$ to $360 \mathrm{ppm}$, while the concentration of 
carbon dioxide increases from about $1.4 \%$ to about $3.1 \%$. The concentration of nitrogen oxides during this time increases from about $63 \mathrm{ppm}$ to about $350 \mathrm{ppm}$, and the concentration of hydrocarbons decreases from about $68 \mathrm{ppm}$ to about $37 \mathrm{ppm}$. Relatively small values of concentrations of particular compounds in the exhaust gases are associated with a large coefficient of excess air in the combustion chamber, which in the case of turbine engines results in a significant dilution of exhaust gases [15].

Using the functional relationships of changes in the concentration of harmful exhaust gas compounds in relation to the engine load factor $\left(\mathrm{W}_{\mathrm{o}}\right)$, a functional dependence of the mass emission intensity of a given harmful compound $\left(\dot{E}_{i, j}\right)$ of the tested engines can be proposed as a function of the engine load factor:

$$
\dot{\mathrm{E}}_{\mathrm{i}, \mathrm{j}}\left(\mathrm{W}_{\mathrm{o}}\right)=\dot{\mathrm{m}}_{\mathrm{spal} \mathrm{j}}\left(\mathrm{W}_{\mathrm{o}}\right) \cdot \mathrm{g}_{\mathrm{i}, \mathrm{j}}\left(\mathrm{W}_{\mathrm{o}}\right)\left[\frac{\mathrm{kg}}{\mathrm{s}}\right]
$$

where: $\dot{\mathrm{m}}_{\mathrm{spal} \mathrm{j}}\left(\mathrm{W}_{\mathrm{o}}\right)$ - exhaust mass stream $[\mathrm{kg} / \mathrm{s}]$ as a function of the engine load factor for the $\mathrm{j}$-th measurement, $g_{i, j}\left(W_{o}\right)$ - mass share [-] of the i-th exhaust component as a function of the engine load factor for the $\mathrm{j}$-th measurement.

The values of mass emission intensity of the analyzed harmful compounds are presented in Figs 9 and 10.

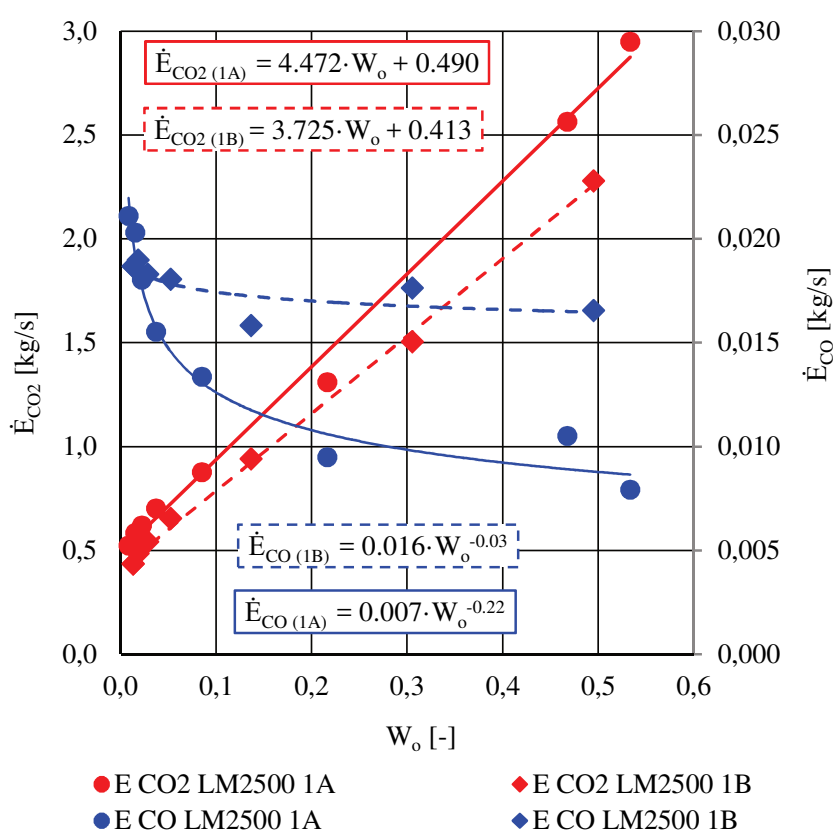

Fig. 9. The mass emission intensity of carbon dioxide $\left(\dot{\mathrm{E}}_{\mathrm{CO} 2}\right)$ and carbon monoxide $\left(\dot{\mathrm{E}}_{\mathrm{CO}}\right)$ in the LM 2500 1A and LM 2500 1B engines exhaust as a function of the engine load factor $\left(\mathrm{W}_{\mathrm{o}}\right)$

The next step in the analysis of emissions of harmful exhaust compounds of LM 2500 engines was to determine the unit emission of individual compounds from the dependence:

$$
e_{i, j}\left(W_{o}\right)=\frac{\dot{E}_{i, j}\left(W_{o}\right)}{W_{o j} \cdot P_{\max }}\left[\frac{k g}{k W \cdot h}\right]
$$

where: $\dot{\mathrm{E}}_{\mathrm{i}, \mathrm{j}}\left(\mathrm{W}_{\mathrm{o}}\right)$ - mass emission intensity $[\mathrm{kg} / \mathrm{h}]$ of the i-th exhaust component as a function of the engine load coefficient for the $\mathrm{j}$-th measurement, $\mathrm{W}_{\mathrm{oj}}$ - engine load factor $[-]$ for the $\mathrm{j}$-th measurement, $\mathrm{P}_{\max }$ - the maximum power of the LM 2500 engine $(24608 \mathrm{~kW})$.

The values of determined unit emissions of individual harmful compounds are presented in Figs 11 and 12.

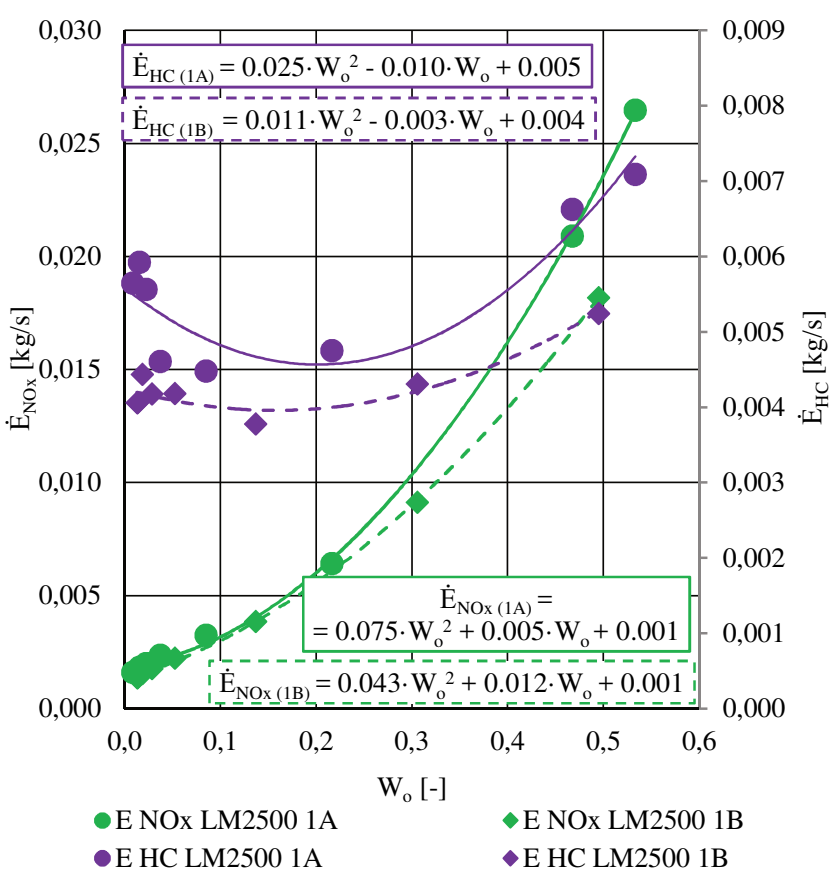

Fig. 10. The mass emission intensity of nitrogen oxides $\left(\dot{\mathrm{E}}_{\mathrm{NOx}}\right)$ and hydrocarbons $\left(\dot{\mathrm{E}}_{\mathrm{HC}}\right)$ in the LM 2500 1A and LM 2500 1B engines exhaust as a function of the engine load factor $\left(\mathrm{W}_{\mathrm{o}}\right)$

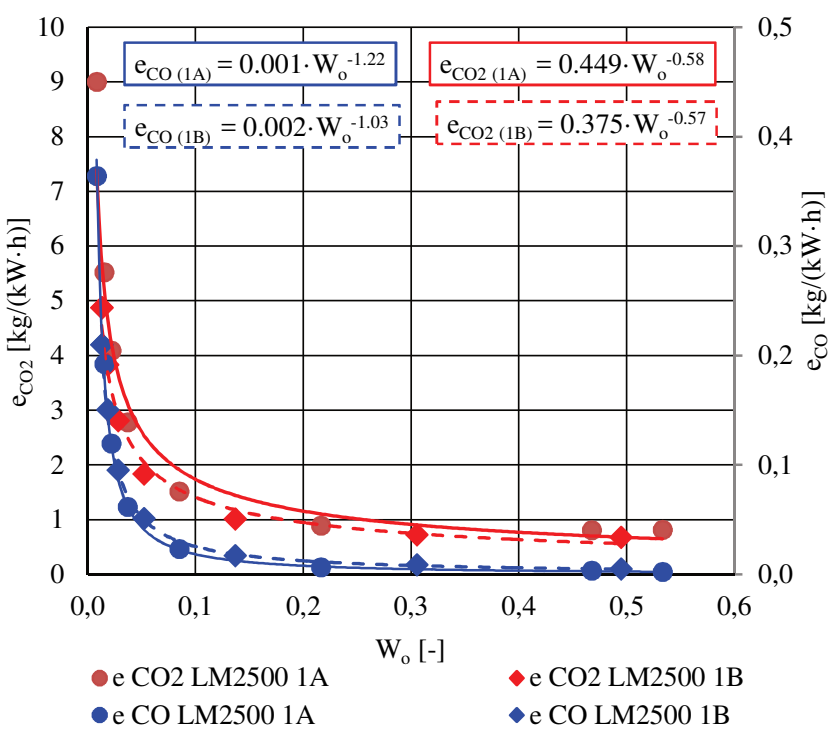

Fig. 11. The unit emission of carbon dioxide $\left(\mathrm{e}_{\mathrm{CO} 2}\right)$ and carbon monoxide $\left(\mathrm{e}_{\mathrm{CO}}\right)$ in the LM $25001 \mathrm{~A}$ and LM $25001 \mathrm{~B}$ engines exhaust as a function of the engine load factor $\left(\mathrm{W}_{\mathrm{o}}\right)$ 


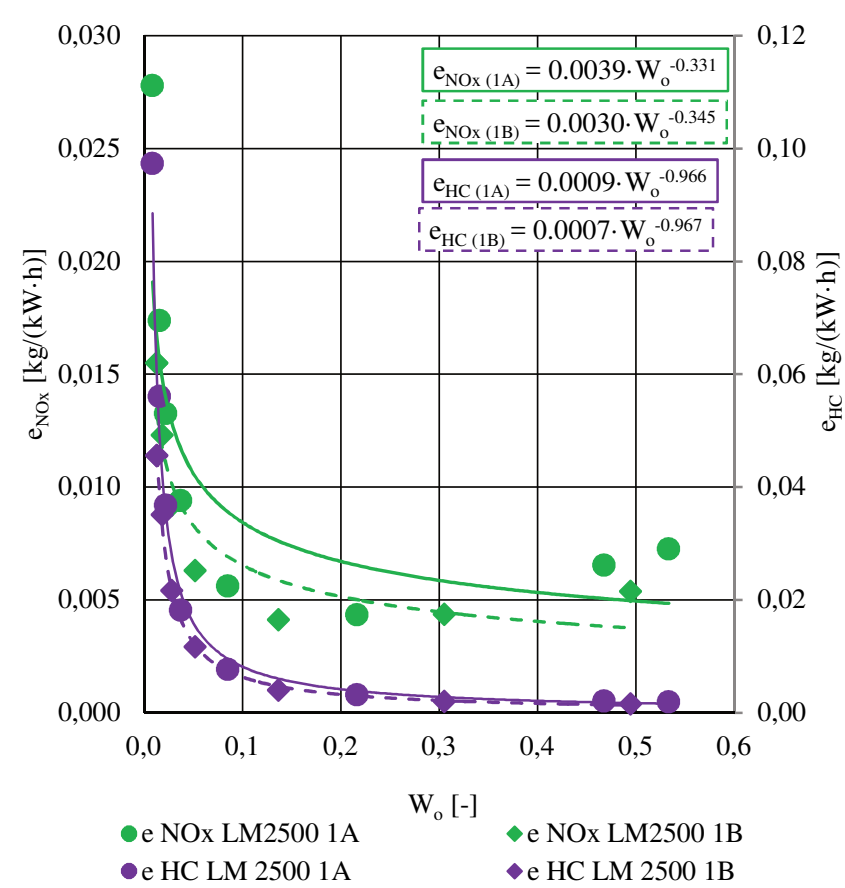

Fig. 12. The unit emission of nitrogen oxides $\left(\mathrm{e}_{\mathrm{NOx}}\right)$ and hydrocarbons $\left(\mathrm{e}_{\mathrm{HC}}\right)$ in the LM $25001 \mathrm{~A}$ and LM 2500 1B engines exhaust as a function of the engine load factor $\left(\mathrm{W}_{\mathrm{o}}\right)$

\section{Conclusions}

On the basis of the conducted research, it can be concluded that the increase in the load on the ship's turbine engine causes a decrease in the concentration of carbon monoxide and an increase in the concentration of carbon dioxide in the exhaust. At the same time, the concentration of nitrogen oxides increases and the concentration of hydrocarbons decreases. The above results from the improvement of the conditions of the combustion process taking place in the combustion chamber of the engine.

Additionally, carried out research and the analysis of the actual working conditions of frigate ships indicate the similarity in the form of the time distribution of engine operation in engine load intervals occurring during the ship's tasks during the cruise. In order to determine the level of emission of harmful compounds contained in the exhaust gas generated by the turbine engines of the main propulsion vessel, an analysis of functional dependence of ecological parameters on the operating parameters were carried out.

The conducted analysis showed the possibility of obtaining mathematical functions describing relations between selected parameters. These functions can be used to assess the mass emission intensity and the unit emission of individual harmful compounds emitted while the engine is running at a given load.

Having the mathematical functions describing the mass emission intensity of the analyzed compounds of harmful exhaust gases of LM 2500 engines and knowing the engine operation time with a given load, there is a possibility to determine the mass of emitted harmful compounds during the operation of the engine with this load.

\section{Nomenclature}

c concentration

$\mathrm{CO}$ carbon monoxide

$\mathrm{CO}_{2}$ carbon dioxide

e unit emission

$\dot{\mathrm{E}}$ mass emission intensity

FFG rocket frigate

g mass share

HC hydrocarbons

KS combustor

LM Lockheed Martin

$\dot{\mathrm{m}}$ mass stream

\section{Indexes}

GG gas generator

i number of exhaust component

j number of measurement

max maximum

$\begin{array}{ll}\mathrm{NO}_{x} & \text { nitrogen oxides } \\ \mathrm{P} & \text { power } \\ \mathrm{PR} & \text { reduction gear } \\ \mathrm{PSK} & \text { space between } \mathrm{S} \text { and } \mathrm{KS} \\ \mathrm{PTT} & \text { space between TWS and TN } \\ \mathrm{S} & \text { compressor } \\ \mathrm{SN} & \text { propeller } \\ \mathrm{TN} & \text { power turbine } \\ \mathrm{TWS} & \text { gas generator turbine } \\ \mathrm{W}_{\mathrm{o}} & \text { engine load factor }\end{array}$

pal, f fuel

PT power turbine

spal exhaust

\section{Bibliography}

[1] AMMAR, N., FARAG, A. CFD modeling of syngas combustion and emissions for marine gas turbine applications. Polish Maritime Research. 2016, 23, 39-49. DOI: 10.1515/pomr-2016-0030

[2] BIAGIOLI, F., GÜTHE, F. Effect of pressure and fuel-air unmixedness on $\mathrm{NO}_{\mathrm{x}}$ emissions from industrial gas turbine burners. Combustion and Flame. 2007, 1511-2, 274-288. DOI: $10.1016 /$ j.combustflame.2007.04.007
[3] COOPER, A. Exhaust emissions from high speed passenger ferries. Atmospheric Environment. 2001, 35, 4189-4200. DOI: $10.1016 / \mathrm{S} 1352-2310(01) 00192-3$

[4] HERDZIK, J. Emissions from marine engines versus IMO certification and requirements of Tier 3. Journal of KONES Powertrain and Transport. 2011, 18(2), 161-167.

[5] HUNICZ, J., KRZACZEK, P. Detailed speciation of emissions from low-temperature combustion in a gasoline 
HCCI engine. Polish Journal of Environmental Studies. 2016, 25, 137-145. DOI: 10.15244/pjoes/60082

[6] HUNICZ, J., MEDINA, A. Experimental study on detailed emissions speciation of an HCCI engine equipped with a three-way catalytic converter. Energy. 2016, 117, 388-397. DOI: $10.1016 /$ j.energy.2016.06.049

[7] KNIAZIEWICZ, T. Process modeling of ship emissions of internal combustion engines for main propulsion under real operating conditions. Polish Naval Academy Press. 2013, 193A.

[8] KOMAR, I., BRANKO, L. Current air quality issues. Sea Transport Air Pollution InTech Open Science. 2015, 165202. DOI: $10.5772 / 58743$

[9] KOWALEWICZ, A. Fundamentals of combustion processes. Publisher Scientific-Technical. 2000.

[10] MARKOWSKI, J., OLEJNICZAK, D., WIRKOWSKI, P. Evaluation of turbine microjet engine operating parameters in conditions conducive to inlet freezing. MATEC Web of Conferences. 2017, 118, 1-5, DOI: 10.1051/matecconf/ 201711800031

[11] MERKISZ, J., PIASECZNY, L., KNIAZIEWICZ, T. Issues emissions of marine engines. Poznan University of

Paweł Wirkowski, DEng. - Faculty of Mechanical and Electrical Engineering, Polish Naval Academy.

e-mail:p.wirkowski@amw.gdynia.pl
Technology Press. Poznan 2016.

[12] NOWACKI, M., OLEJNICZAK, D. Analysis of Boeing 737 MAX 8 flight in terms of the exhaust emission for selected flight. Transportation Research Procedia. 2018, 35, 158165. DOI: $10.1016 /$ j.trpro.2018.12.033

[13] WIRKOWSKI, P., KNIAZIEWICZ, T. Evaluation of marine gas turbine engine parameters in terms of issue of emissions of exhaust toxic fumes. Combustion Engines. 2017, 171(4), 87-91. DOI: 10.19206/CE-2017-415

[14] WIRKOWSKI, P., MARKOWSKI, J., KNIAZIEWICZ, T. Initial tests of emissions of harmful compounds in the exhaust of a marine gas turbine engine in operating conditions. IOP Conference Series: Materials Science and Engineering. 2018, 421, 042079, 1-10. DOI: 10.1088/1757$899 X / 421 / 4 / 042079$

[15] ZADRĄG, R., KNIAZIEWICZ, T. Ranking of toxic compound concentrations as diagnostic parameters of marine internal combustion engine. Polish Maritime Research. 2018, 25, 234-242. DOI: 10.2478/pomr-20180047

[16] https://www.google.pl/search?q=fregata +273

[17] https://www.centerfieldinc.com/lm2500

Jarosław Markowski, DSc., DEng. - Institute of Internal Combustion Engines and Transport, Poznan University of Technology.

e-mail: jaroslaw.markowski@put.poznan.pl 